\title{
PENERAPAN K-MEANS CLUSTERING UNTUK SELEKSI FRAME DOMINAN BERBASIS NTSC PADA OBYEK BERGERAK
}

\author{
Rizka Indah Armianti ${ }^{1}$, Achmad Fanany Onnilita Gaffar ${ }^{2}$, Arief Bramanto Wicaksono Putra ${ }^{\text {** }}$ \\ ${ }^{123}$ Program Studi Teknik Informatika Multimedia, Politeknik Negeri Samarinda, Indonesia \\ Email: ${ }^{1}$ rizkaindaharmyanti@gmail.com, ${ }^{2}$ onnygaffar212@gmail.com, ${ }^{3}$ ariefbram@gmail.com \\ *Penulis Korespondensi
}

(Naskah masuk: 7 Juli 2019, diterima untuk diterbitkan: 10 September 2019)

\begin{abstract}
Abstrak
Obyek dinyatakan bergerak jika terjadi perubahan posisi dimensi disetiap frame. Pergerakan obyek menyebabkan obyek memiliki perbedaan bentuk pola disetiap frame-nya. Frame yang memiliki pola terbaik diantara frame lainnya disebut frame dominan. Penelitian ini bertujuan untuk menyeleksi frame dominan dari rangkaian frame dengan menerapkan metode K-means clustering untuk memperoleh centroid dominan (centroid dengan nilai tertinggi) yang digunakan sebagai dasar seleksi frame dominan. Dalam menyeleksi frame dominan terdapat 4 tahapan utama yaitu akuisisi data, penetapan pola obyek, ekstrasi ciri dan seleksi. Data yang digunakan berupa data video yang kemudian dilakukan proses penetapan pola obyek menggunakan operasi pengolahan citra digital, dengan hasil proses berupa pola obyek RGB yang kemudian dilakukan ekstraksi ciri berbasis NTSC dengan menggunakan metode statistik orde pertama yaitu Mean. Data hasil ekstraksi ciri berjumlah 93 data frame yang selanjutnya dikelompokkan menjadi 3 cluster menggunakan metode K-Means. Dari hasil clustering, centroid dominan terletak pada cluster 3 dengan nilai centroid 0.0177 dan terdiri dari 41 data frame. Selanjutnya diukur jarak kedekatan seluruh data cluster 3 terhadap centroid, data yang memiliki jarak terdekat dengan centroid itulah frame dominan. Hasil seleksi frame dominan ditunjukkan pada jarak antar centroid dengan anggota cluster, dimana dari seluruh 41 data frame tiga jarak terbaik diperoleh adalah 0.0008 dan dua jarak bernilai 0.0010 yang dimiliki oleh frame ke-59, ke-36 dan ke-35.
\end{abstract}

Kata kunci: Frame Dominan, K-Means Clustering, Pola Obyek, Seleksi Frame Dominan.

\section{APPLICATION OF K-MEANS CLUSTERING FOR NTSC-BASED DOMINANT FRAME SELECTION ON MOVING OBJECTS}

\begin{abstract}
The object is declared moving if there is a change in the position of the dimensions in each frame. The movement of an object causes the object to have different shapes in each frame. The frame that has the best pattern among other frames is called the dominant frame. This study aims to select the dominant frame from the frame set by applying the K-means clustering method to obtain the dominant centroid (the highest value centroid) which is used as the basis for the selection of dominant frames. In selecting dominant frames, there are 4 main stages, namely data acquisition, determination of object patterns, feature extraction and selection. The data used in the form of video data which is then carried out the process of determining the pattern of objects using digital image processing operations, with the results of the process in the form of an RGB object pattern which is then performed NTSC-based feature extraction using the first-order statistical method, Mean. The data from feature extraction are 93 data frames which are then grouped into 3 clusters using the K-Means method. From the results of clustering, the dominant centroid is located in cluster 3 with a centroid value of 0.0177 and consists of 41 data frames. Furthermore, the proximity of all data cluster 3 to the centroid is measured, the data having the closest distance to the centroid is the dominant frame. The results of dominant frame selection are shown in the distance between centroids and cluster members, where from all 41 data frames the three best distances obtained are $0.0008,0.0010$, and 0.0010 owned by 59th, 36th and 35th frames.
\end{abstract}

Keywords: Object Patterns, Dominant Frames, Dominant Frame Selection, K-Means Clustering.

\section{PENDAHULUAN}

Video merupakan suatu rangkaian citra yang terekam oleh sensor kamera dalam satuan waktu.
Citra yang tersusun dalam sebuah video disebut frame. Di dalam sebuah video terdapat obyek yang terkandung di dalamnya. Obyek tersebut dapat mengalami perubahan posisi dimensi disetiap frame 
atau biasa disebut dengan obyek bergerak. Pergerakan obyek tersebut menghasilkan perbedaan bentuk pola obyek pada tiap frame-nya, yang artinya tiap-tiap frame memiliki bentuk pola obyek yang berbeda-beda meskipun obyek yang digunakan sama (Putra et al., 2018).

Pola yang terkandung dalam suatu citra sangat berpengaruh dalam menentukan frame dominan dari suatu rangkaian frame. Frame dominan adalah frame yang memiliki pola terbaik diantara frame lainnya. Pola terbaik merupakan pola yang memiliki corak gambar paling banyak, dan memiliki nilai ciri pola yang tinggi. Pola diperoleh dari corak gambar yang dimiliki oleh masing-masing frame. Dari pola yang dimiliki masing-masing frame kemudian di seleksi frame mana yang memiliki pola terbaik diantara frame lainnya. Karena pergerakan obyek yang terekam dengan cepat, kemampuan penglihatan manusia tidak dapat mengidentifikasi frame mana yang memiliki pola terbaik diantara frame lainnya sebab dipengaruhi oleh subjektivitas manusia.

Untuk meminimalisir kondisi tersebut, dibutuhkannya kemampuan sistem penglihatan komputer (computer vision) untuk memproses, menganalisis dan menafsirkan citra dari dunia nyata dengan tujuan untuk menghasilkan informasi numerik atau simbolis (Putri, 2018). yang kemudian hasil informasi tersebut dilakukan penerapan metode K-Means Clustering untuk mengelompokkan frame bedasarkan tingkat pola terbaik. Cluster dengan nilai centroid tertinggi (centroid dominan) pada iterasi (perulangan) akhir yang akan digunakan sebagai dasar seleksi frame dominan, sebab frame dominan terletak di cluster yang memiliki nilai centroid tertinggi. Kemudian cluster dengan centroid dominan tersebut dilakukan proses pemeringkatan berdasarkan jarak minimum anggota cluster dengan centroid-nya. Anggota cluster yang memiliki nilai jarak ter-minim atau terkecil terhadap centroid itulah frame dominan (Putra et al., 2019).

Ciri yang bagus adalah ciri yang memiliki daya pembeda yang tinggi, sehingga pengelompokan frame bedasarkan ciri pola yang dimiliki dapat dilakukan dengan tingkat keakuratan yang tinggi (Munir, 2004). Peta warna NTSC memiliki daya pembeda yang lebih tinggi dari peta warna RGB, sehingga ektraksi ciri pola menggunakan basis komponen warna NTSC akan menghasilkan hasil yang lebih baik dari komponen warna RGB sebab peta warna RGB tidak dapat memodelkan dan mendefinisikan warna secara dalam karena peta warna RGB bergantung pada tiga komponen primer warna yaitu Red (merah), Green (hijau), dan Blue (biru) (Kotsarenko and Ramos, 2010).

Peneltian menggunakan algoritma untuk mengembangkan ekstraksi keyframe dengan mengambil asumsi bahwa konten yang lebih menonjol dan yang lebih penting yang akan digunakan dalam ekstrasi tersebut. Dengan menggunakan Unsupervised Clustering sebagai basis untuk membagi frame ke dalam beberapa kelompok, serta menggunakan model statistika untuk menghitung ambang batas (threshold) pengelompokan dan kemudian keyframe dipilih dari masing-masing kandidat cluster (Shuping and Xinggang, 2005).

Dari beberapa penjelasan uraian diatas mengacu pada seleksi frame dominan dari data hasil akuisisi citra digital berupa video dengan obyek yang bergerak atau obyek yang mengalami perubahan posisi dimensi disetiap frame. Pada penelitian ini menggunakan tahapan awal penetapan pola obyek, sehingga obyek bergerak pada video yang digunakan berupa geometri bola yang cukup handal untuk ditemukan polanya menggunakan teknik region of interest (ROI). Peta warna NTSC menjadi basis dari proses ekstraksi ciri. Penerapan metode K-Means Clustering untuk mengelompokkan frame bedasarkan tingkat pola terbaik. Cluster dengan nilai tertinggi pada centroid (titik tengah) akhir digunakan sebagai dasar untuk menyeleksi frame dominan.

Adapun Kerangka Konsep penelitian ini disajikan dalam Gambar 1.

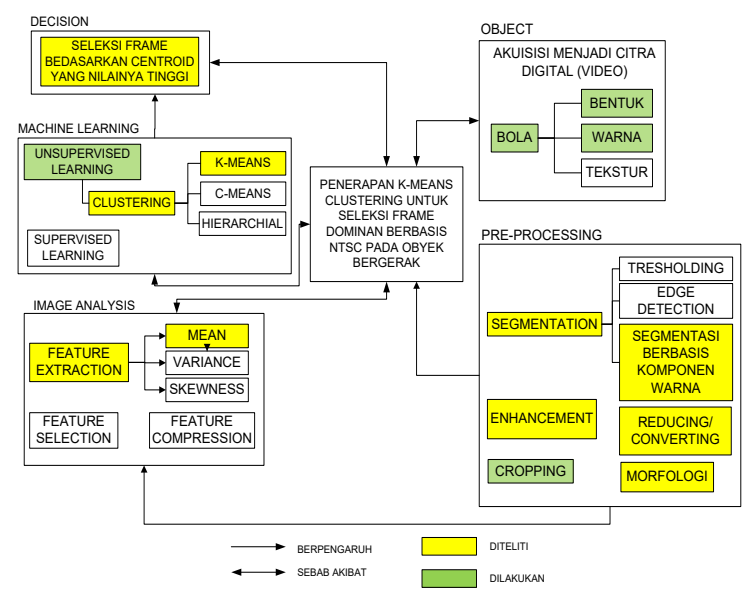

Gambar 1. Kerangka Konsep Penelitian

\section{METODE PENELITIAN}

Tahapan-tahapan yang dilakukan dalam penelitian ini meliputi akuisisi citra digital, penetapan pola obyek, ekstraksi ciri dan seleksi. 4 tahapan utama tersebut disajikan dalam Gambar 2.

\subsection{Akuisisi Citra Digital}

Akuisisi citra digital merupakan tahapan atau proses untuk mendapatkan citra digital (Zhou et al., 2014a). Data yang diperoleh dari proses akuisisi yaitu berupa data video dengan obyek bola yang bergerak. Data video diperoleh dengan menggunakan sensor kamera digital pocket, dengan background, pencahayaan, serta tata letak posisi obyek dan kamera yang telah diatur. Proses akuisisi citra digital dalam penelitian ini disajikan dalam Gambar 3. 


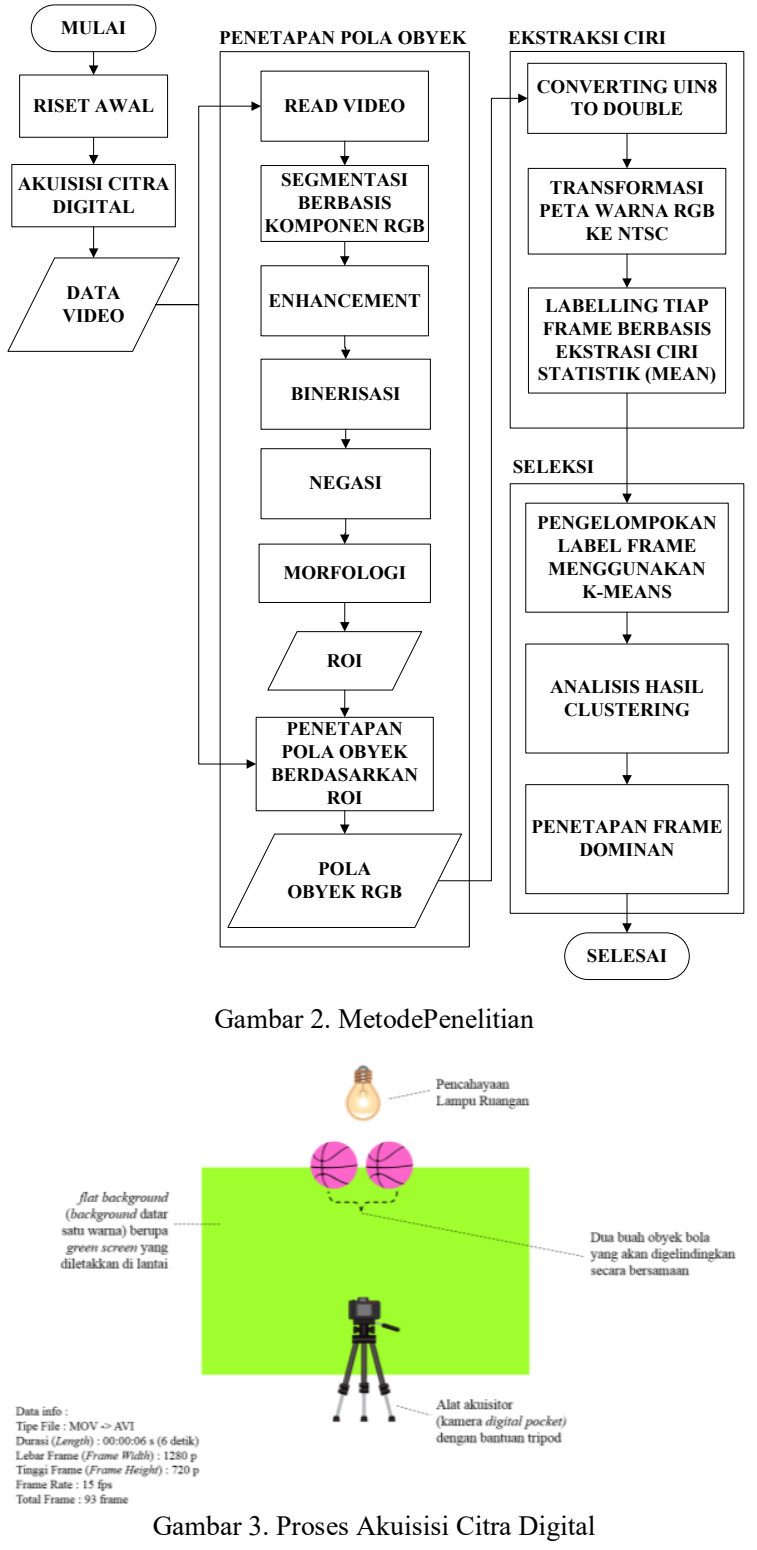

\subsection{Penetapan Pola Obyek}

Setelah dilakukan proses akuisisi data, data video kemudian dilakukan pembacaan data menggunakan program komputasi komputer. Setelah data video terbaca kemudian dilakukan ekstraksi frame ke dalam memory penyimpanan data gambar (CData). Setelah deretan frame berhasil diekstraksi, dilakukan proses penetapan pola obyek selanjutnya yaitu (Putri et al., 2018):

1) Segementasi berbasis komponen RGB

Segmentasi bertujuan untuk memisahkan obyek dengan background. Citra true color (RGB) merupakan sebuah citra yang terdiri dari 3 (tiga) komponen citra gray (Red,Green,Blue), yang dimana dapat dilakukan proses segmentasi warna secara langsung dengan cara memperkurangkan antar komponen citra (Sari et al., 2018) seperti yang disajikan dalam Gambar 4.

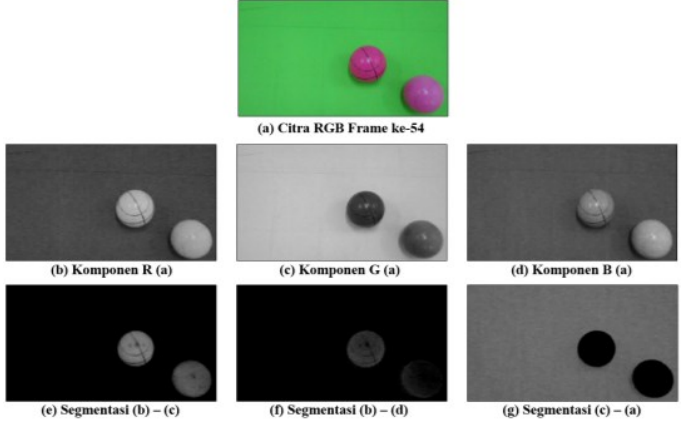

Gambar 4. Segmentasi Berbasis Komponen RGB

Berdasarkan Gambar 4. hasil pengurangan antar komponen warna yang menghasilkan segmentasi citra terbaik dalam penelitian ini yaitu pengurangan komponen warna G-B, sebab pola obyek telah terdefinisi dengan jelas.

\section{2) Peregangan Kontras}

Dari hasil segmentasi berbasis komponen RGB yang telah dilakukan sebelumnya, perlu dilakukan proses perbaikan citra (Image Enhancement) sebab hasil pola obyek yang diinginkan belum terlihat tegas (Firdausy et al., 2007), sehingga dilakukan operasi peregangan kontras seperti yang disajikan dalam Gambar 5.

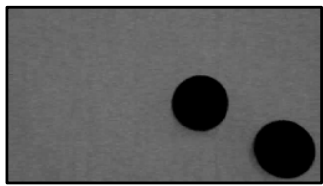

(a) Citra Hasil Segmentasi Komponen RGB (G-B) Frame ke-54

$$
\text { Gambar 5. Operasi Peregangan Kontras }
$$

\section{3) Binerisasi}

Binerisasi dilakukan ntuk menyempurnakan hasil segmentasi berbasis komponen RGB yang telah dilakukan proses enhancement sebelumnya, sebab hasil segementasi masih mengandung citra keabuan yang dimana pola obyek yang diinginkan belum teridentifikasi dengan tegas (Kadir and Santoso, 2013). Proses binerisasi menggunakan nilai ambang (threshold) untuk menentukan nilai graylevel yang dirubah menjadi citra binary dengan piksel bernilai 0 (hitam) atau 1 (putih). Nilai graylevel citra yang lebih dari atau yang sama dengan nilai ambang (threshold) akan dirubah menjadi piksel bernilai 1 (berwarna putih) sedangkan nilai graylevel citra yang kurang dari nilai threshold akan dirubah menjadi piksel bernilai 0 (berwarna hitam). Hasil proses binerisasi disajikan dalam Gambar 6.

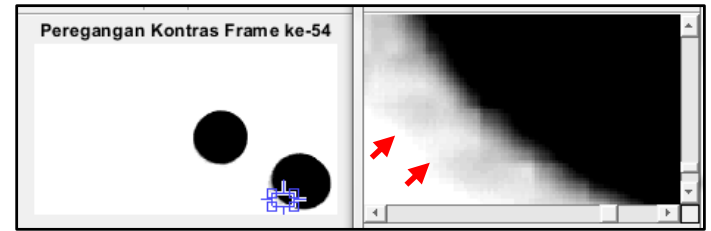

(a) Citra Hasil Peregangan Kontras Frame Ke-54 


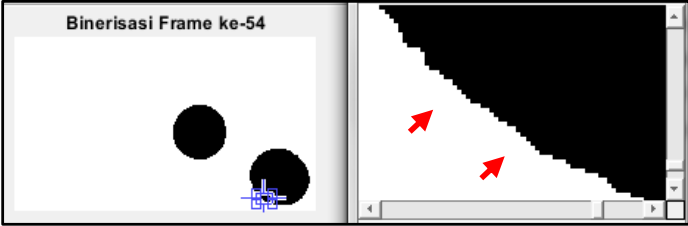

(b) Binerisasi (a)

Gambar 6. Citra Hasil Binerisasi

\section{4) Negasi}

Dari hasil proses binerisasi pola obyek yang diinginkan masih dalam piksel bernilai 0 (hitam) dan background dalam piksel bernilai 1 (putih) yang kemudian perlu dilakukan proses negasi untuk membalikkan nilai-nilai tiap piksel warna, dengan nilai piksel pola obyek yang dibalik menjadi piksel bernilai 1 (putih) dan background menjadi piksel bernilai 0 (hitam) (Syafi'i et al., 2015). Proses negasi bertujuan untuk mempermudah proses analisis citra (seperti proses perhitungan) serta membuang pikselpiksel yang tidak diinginkan (noise). Hasil proses negasi disajikan dalam Gambar 7.

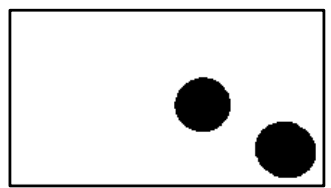

(a) Citra Hasil Binerisasi Frame ke-54

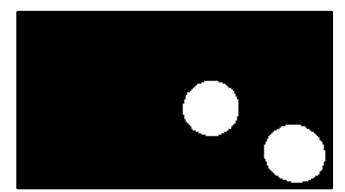

(b) Negasi (a)
Gambar 7. Citra Hasil Negasi

\section{5) Erosi}

Erosi merupakan operasi morfologi yang melakukan penyusutan atau penipisan obyek dengan menghilangkan piksel pada batas obyek menggunakan bentuk dari elemen struktur (SE) (Zhou et al., 2014b). Dalam penelitian ini erosi digunakan untuk memperbaiki ROI pola obyek dari citra hasil negasi serta menghilangkan piksel-piksel yang tidak dominan agar tidak menjadi noise pada ROI pola obyek. Hasil proses morfologi erosi dengan menggunakan elemen struktur "disk" disajikan dalam Gambar 8.

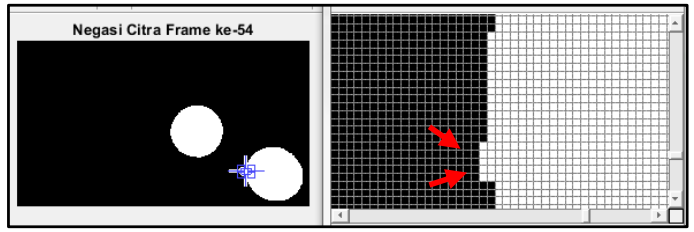

(a) Citra Hasil Negasi Frame ke-54

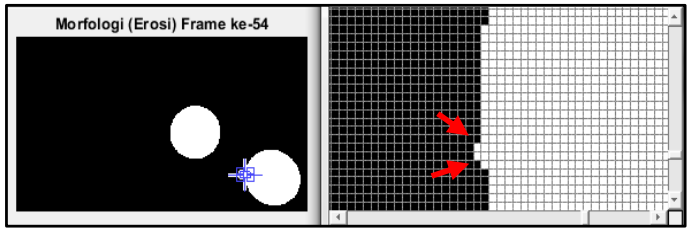

(b) Morfologi Erosi (a)

Gambar 8. Citra Hasil Morfologi Erosi

6) Cropping RGB

Citra biner dari hasil operasi morfologi erosi menghasilkan ROI pola obyek yang kemudian digunakan sebagai informasi lokasi obyek untuk melakukan proses Cropping (pengambilan) terhadap data citra asli (true color) secara otomatis pada seluruh rangkaian frame. Hasil dari proses Cropping RGB menghasilkan pola obyek RGB seperti yang disajikan dalam Gambar 9.

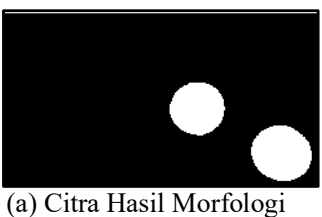

(a) Citra Hasil Morfologi

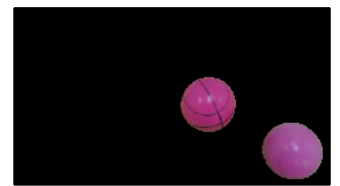

(c) Cropping (b) dengan basis (a)

Gambar 9. Cropping RGB Frame ke-54

\subsection{Ekstraksi Ciri}

Setelah selesai melakukan tahap penetapan pola obyek, tahap selanjutnya yaitu tahap Ekstraksi Ciri. Data citra hasil penetapan pola obyek akan dianalisis untuk diambil ciri pola yang terkandung di dalamnya, yang dimana hasil ciri tersebut akan digunakan sebagai label frame.

\section{1) Converting Uint8 to Double}

Konversi tipe data uint8 ke double dilakukan agar proses aritmatika pada matriks dapat dilakukan.

\section{2) Converting $R G B$ to NTSC}

Konversi peta warna RGB ke NTSC dilakukan karena peta warna NTSC yang terdiri dari komponen Luminance $(Y)$, Chrominance (I dan $Q$ ) memiliki daya pembeda yan tinggi. Dimana pada tahap selanjutnya komponen YIQ akan digunakan sebagai atribut ciri yang menandai sebuah pola dari setiap frame-nya. Ciri yang bagus adalah ciri yang memiliki daya pembeda yang tinggi, sehingga pengelompokan frame bedasarkan ciri pola yang dimiliki dapat dilakukan dengan tingkat keakuratan yang tinggi. Komponen YIQ diperoleh dari transformasi ruang warna RGB ke ruang warna NTSC, seperti ditunjukkan pada transformasi Persamaan (1).

$$
\left[\begin{array}{l}
Y \\
I \\
Q
\end{array}\right]=\left[\begin{array}{rrr}
0,299 & 0,587 & 0,114 \\
0,596 & -0,274 & -0,322 \\
0,211 & -0,523 & 0,312
\end{array}\right]\left[\begin{array}{l}
R \\
G \\
B
\end{array}\right]
$$

\section{3) Mean $(\mu)$}

Metode ekstraksi ciri yang digunakan yaitu ekstraksi ciri statistik orde pertama $($ Mean $(\mu))$. Mean merupakan ekstraksi ciri statistik yang menghitung 
jumlah nilai keseluruhan piksel pada region pola yang kemudian dibagi dengan jumlah total piksel pada region pola tersebut. Rumus perhitungan metode ekstraksi ciri statistik orde pertama (Mean $(\mu))$ menggunakan Persamaan (2).

$(\mu)=\frac{\text { jumlah nilai keseluruhan piksel pada region }}{\text { total piksel pada region }}$

\subsection{Seleksi}

Pada tahap seleksi, label frame akan dikelompokkan menggunakan metode K-Means Clustering bedasarkan tingkat pola terbaik. Dari hasil clustering tersebut akan diperoleh centroid dominan (centroid dengan nilai tertinggi), yang digunakan sebagai dasar seleksi frame dominan.

\section{1) K-Means Clustering}

Algoritma K-Means clustering dimulai dengan memilih titik representatif $\mathrm{K}$ sebagai centroid (pusat massa) awal. Setiap titik kemudian ditugaskan ke jarak yang terdekat dari centroid berdasarkan ukuran jarak kedekatan tertentu yang dipilih. Setelah cluster terbentuk, pusat massa (centroid) untuk setiap cluster diperbarui. Algoritma ini kemudian melakukan perulangan, mengulangi kedua langkah sebelumnya hingga anggota cluster tidak mengalami perubahan (Aggarwal and Reddy, 2013). Rumus persamaan jarak Euclidean ditunjukkan pada Persamaan (3).

$\mathrm{d}\left(\left[\mathrm{x}_{1}, \mathrm{x}_{2}, \ldots, \mathrm{x}_{\mathrm{n}}\right),\left[\mathrm{y}_{1}, \mathrm{y}_{2}, \ldots, \mathrm{y}_{\mathrm{n}}\right]\right)=\sqrt{\sum_{\mathrm{i}=1}^{\mathrm{n}}\left(\mathrm{x}_{\mathrm{i}}-\mathrm{y}_{\mathrm{i}}\right)^{2}}$

Keterangan :

$\mathrm{d}\left(\left(\mathrm{x}_{1}, \ldots \mathrm{x}_{\mathrm{n}}\right),\left(\mathrm{y}_{1}, \ldots \mathrm{y}_{\mathrm{n}}\right)=\right.$ Jarak data ke $\mathrm{x}$ ke pusat cluster $\mathrm{y}$.

$x_{\mathrm{i}}=$ Data ke i.

$y_{\mathrm{i}}=$ Pusat cluster ke $\mathrm{i}$.

\section{2) Seleksi Frame Dominan}

Pada proses penyeleksian frame, Cluster yang terdiri dari centroid dominan (centroid dengan nilai tertinggi) akan dilihat jarak kedekatan antar datanya terhadap centroid. Data yang memiliki jarak terdekat dengan centroid, itulah frame dominan.

\section{HASIL DAN PEMBAHASAN}

Data video yang diperoleh dari hasil akuisisi citra digital, terlebih dahulu dilakukan penetapan pola obyek. Adapun beberapa proses yang dilakukan yaitu read frame, segmentasi berbasis komponen RGB, kombinasi kecerahan dan kontras, binerisasi, negasi, morfologi (erosi), dan cropping RGB. Data hasil penetapan pola obyek berupa pola obyek RGB, yang disajikan dalam Gambar 10.

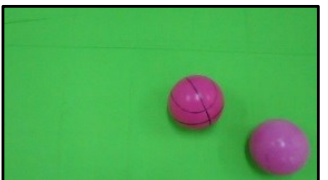

(a) Citra RGB Frame ke-54

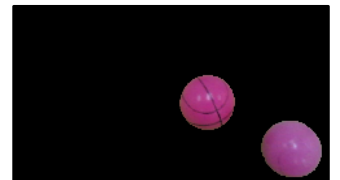

(b) Cropping RGB (a)
Gambar 10. Data Citra Hasil Sebelum dan Sesudah Penetapan Pola Obyek

Data pola obyek RGB kemudian dilakukan ekstraksi ciri untuk mengambil informasi yang terkandung di dalamnya dengan menggunakan metode ekstraksi ciri statistik orde pertama yaitu Mean yang disajikan dalam Persamaan (2), dengan komponen warna yang digunakan yaitu komponen Y,I,dan Q dari peta warna NTSC. Data hasil ekstraksi ciri ditunjukkan dalam Tabel 1.

\begin{tabular}{cccc} 
Tabel 1. Data Hasil Ekstraksi Ciri Pola Tiap Frame \\
\hline Frame ke- & Y & I & Q \\
\hline 1 & 0.0000 & 0.0000 & 0.0000 \\
2 & 0.0000 & 0.0000 & 0.0000 \\
$\ldots \ldots$ & $\ldots \ldots$ & $\ldots \ldots$ & $\ldots \ldots$ \\
91 & 0.0133 & 0.0063 & 0.0056 \\
92 & 0.0132 & 0.0063 & 0.0055 \\
93 & 0.0131 & 0.0063 & 0.0055 \\
\hline
\end{tabular}

Pada Tabel 1. Menghasilkan ciri dengan total jumlah data 93 data frame. Frame ke 1 hingga frame ke 11 memiliki data 0 (nol), sebab obyek baru muncul pada frame ke 12 , data frame yang disajikan dalam Tabel 1. yaitu data frame ke 1,2,91 hingga frame ke 93 dengan label ciri yang dimiliki tiap frame yaitu berupa komponen Y,I,Q. Data hasil ekstraksi ciri pola tiap frame akan digunakan sebagai atribut data frame atau label frame dalam tahap clustering.

Data hasil ekstraksi ciri atau label frame akan di kelompokkan bedasarkan tingkat pola terbaik dengan menggunakan metode K-Means clustering. proses awal clustering yaitu dimulai dengan menentukan jumlah cluster dan inisialisasi anggota cluster. Dalam penelitian ini label frame akan dikelompokkan menjadi 3 cluster. Setelah jumlah cluster dan inisialisasi anggota cluster ditentukan, selanjutnya dilakukan inisialisasi centroid awal. Jika data akan dikelompokkan menjadi 3 cluster maka diperlukan 3 inisialisasi centroid awal. 3 centroid awal diperoleh menggunakan scattered averaging technique (teknik rata-rata tersebar). Algoritma teknik rata-rata tersebar disajikan dalam bentuk flowchart proses dalam Gambar 11.

Dari algoritma Gambar 11 diperoleh 3 centroid awal yang disajikan dalam Tabel 2 .

Tabel 2. Centroid Awal

\begin{tabular}{cccc}
\hline \multicolumn{4}{c}{ Centroid Awal } \\
\hline Cluster & X & Y & Z \\
\hline 1 & 0.0067 & 0.0028 & 0.0019 \\
2 & 0.0176 & 0.0081 & 0.0073 \\
3 & 0.0314 & 0.0119 & 0.0124
\end{tabular}




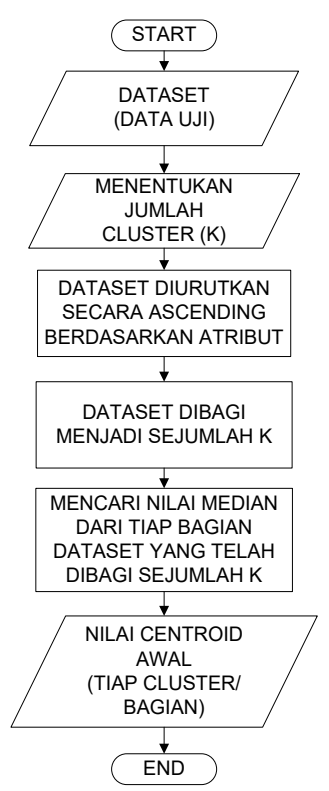

Gambar 11. Algoritma scattered averaging technique (teknik rata-rata tersebar)

Setelah centroid awal ditentukan selanjutnya proses menghitung jarak tiap data yang disajikan dalam Tabel 1. terhadap centroid yang disajikan dalam Tabel 2. menggunakan ukuran jarak Euclidean yang disajikan dalam Persamaan (3). Hasil dari proses perhitungan iterasi awal jarak Euclidean setiap data terhadap centroid disajikan dalam Tabel 3.

Tabel 3. Euclidean Distance Data Terhadap Centroid

\begin{tabular}{cccc}
\hline \multicolumn{5}{c}{ Euclidean Distance } \\
\hline Frame ke- & C1 & C2 & C3 \\
\hline 1 & 0.0075 & 0.0207 & 0.0358 \\
2 & 0.0075 & 0.0207 & 0.0358 \\
$\ldots \ldots$. & $\ldots \ldots \ldots$. & $\ldots \ldots \ldots$ & $\ldots \ldots \ldots$ \\
91 & 0.0083 & 0.0050 & 0.0201 \\
92 & 0.0082 & 0.0051 & 0.0203 \\
93 & 0.0081 & 0.0052 & 0.0203 \\
\hline
\end{tabular}

Hasil dari proses perhitungan jarak Euclidean, kemudian akan dilakukan pengelompokan data berdasarkan jarak terdekat. Jika hasil dari proses perhitungan jarak Euclidean setiap data terhadap centroid merupakan anggota cluster maka dinyatakan dengan 1 dan jika buka anggota cluster maka dinyatakan dengan 0 , seperti yang disajikan dalam Tabel 4.

Tabel 4. Keanggotaan Cluster Iterasi Awal

\begin{tabular}{cccc}
\hline \multicolumn{4}{c}{ Matriks Keanggotaan } \\
\hline Frame ke- & Cluster 1 & Cluster 2 & Cluster 3 \\
\hline $\mathbf{1}$ & 1 & 0 & 0 \\
$\mathbf{2}$ & 1 & 0 & 0 \\
$\ldots \ldots .$. & $\ldots \ldots \ldots$ & $\ldots \ldots \ldots$ & $\ldots \ldots \ldots$ \\
$\mathbf{9 1}$ & 0 & 1 & 0 \\
$\mathbf{9 2}$ & 0 & 1 & 0 \\
$\mathbf{9 3}$ & 0 & 1 & 0 \\
\hline
\end{tabular}

Apabila pada saat proses perhitungan jarak terdekat terjadi adanya perubahan anggota cluster, maka perlu membangkitkan centroid baru untuk iterasi berikutnya berdasarkan rata-rata anggota cluster dan apabila tidak terjadinya perubahan anggota cluster maka proses perhitungan atau iterasi dihentikan. Pada proses perhitungan jarak terdekat dari iterasi awal, terjadinya perubahan anggota cluster, sehingga perlu dilakukan pembangkitan centroid baru.

Hasil pembangkitan centroid baru terhadap data uji untuk tiap cluster dari iterasi awal, diperoleh nilai centroid baru sebagai berikut :

$$
\begin{aligned}
& \mathrm{C} 1=\left[\begin{array}{lll}
0.0021 & 0.0008 & 0.0006
\end{array}\right] \\
& \mathrm{C} 2=\left[\begin{array}{lll}
0.0156 & 0.0070 & 0.0064
\end{array}\right] \\
& \mathrm{C} 3=\left[\begin{array}{lll}
0.0308 & 0.0111 & 0.0116
\end{array}\right]
\end{aligned}
$$

Setelah memperoleh centroid baru langkah selanjutnya yaitu melakukan proses perhitungan kembali, yaitu langkah perhitungan euclidean distance, proses pengelompokan berdasarkan jarak terdekat, pengecekan perubahan anggota cluster, hingga proses pembangkitan centroid baru yang akan dilakukan jika adanya perubahan anggota cluster. Langkah-langkah tersebut akan terus diulang hingga tidak adanya perubahan anggota cluster, dan proses iterasi dihentikan.

Dalam penelitian ini menghasilkan 3 kali iterasi yang juga mengartikan bahwa dilakukannya proses perhitungan serta pembangkitan centroid sebanyak 3 kali hingga tidak adanya perubahan anggota. Adapun data hasil clustering dan data centroid dari hasil iterasi akhir (iterasi ke-3) yang disajikan dalam Tabel 5. dan Tabel 6.

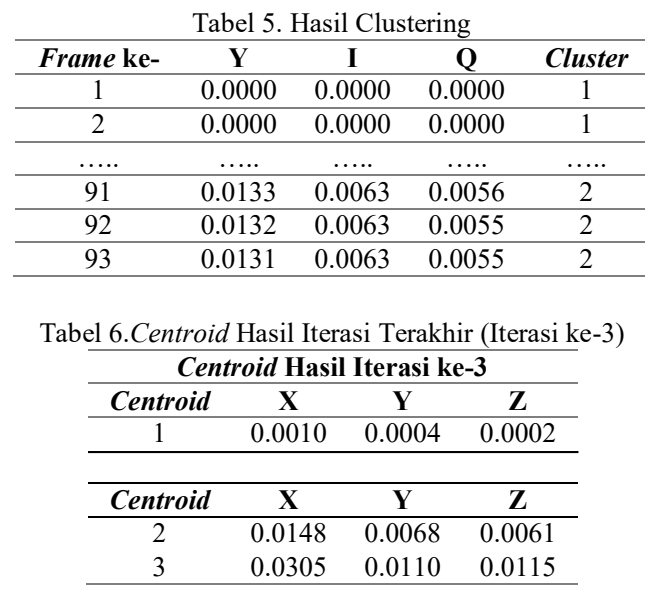

Berdasarkan Tabel 5, pola persebaran keanggotaan cluster dapat di visualisasi melalui visualisasi gambar pemetaan (plotting) seperti yang ditunjukkan pada Gambar 12. dan Gambar 13.

Berdasarkan Gambar 12. dan Gambar 13. pemetaan (plotting) dengan 3 cluster menggunakan atribut komponen (Luminance (Y) - Chrominance (I) dan Luminance (Y) - Chrominance (Q)) dari iterasi akhir diketahui pola perseberan keanggotaan cluster 1 memiliki nilai ciri pola yang rendah, cluster 2 memiliki nilai ciri pola yang cukup tinggi, dan cluster 3 memiliki nilai ciri pola yang tinggi. 


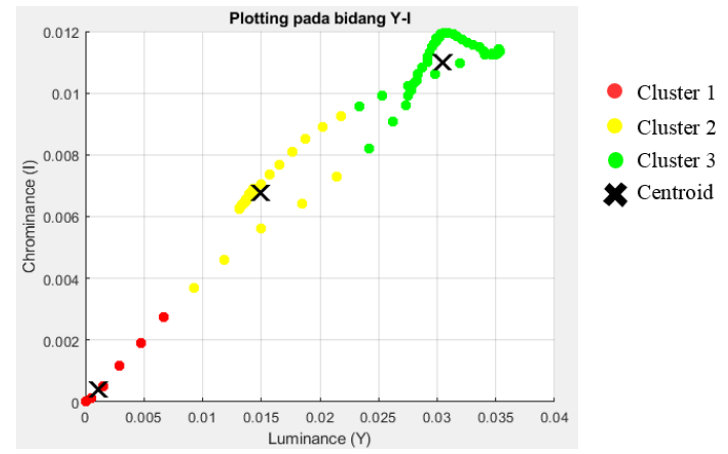

Gambar 12. Visualisasi Gambar Pemetaan (Plotting) Dengan 3 Cluster Menggunakan Atribut Komponen (Luminance (Y) Chrominance (I))

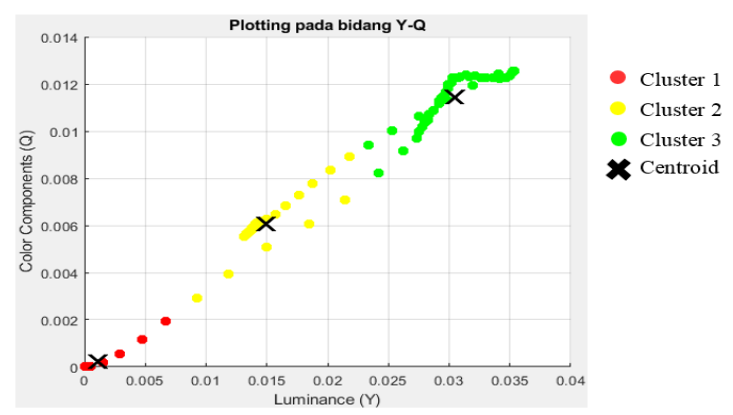

Gambar 13. Visualisasi Gambar Pemetaan (Plotting) Dengan 3 Cluster Menggunakan Atribut Komponen (Luminance (Y) Chrominance (Q))

Frame dominan adalah frame yang memiliki pola terbaik diantara frame lainnya, pola terbaik merupakan pola yang memiliki corak gambar paling banyak, dan memiliki nilai ciri pola yang tinggi. Sehingga cluster yang memiliki nilai centroid tertinggi yang akan digunakan sebagai dasar untuk seleksi frame dominan. Untuk mengetahui letak cluster yang memiliki nilai centroid tertinggi, yaitu dengan cara merata-ratakan nilai seluruh atribut komponen tiap cluster dari hasil centroid iterasi akhir (iterasi ke-3) seperti ditunjukkan pada Tabel 7.

\begin{tabular}{ccccc}
\multicolumn{5}{c}{ Tabel 7. Seleksi Centroid Dominan } \\
\hline Centroid Hasil Iterasi ke-3 \\
\hline Centroid & X & Y & Z & Average \\
\hline 1 & 0.0010 & 0.0004 & 0.0002 & 0.0006 \\
2 & 0.0148 & 0.0068 & 0.0061 & 0.0092 \\
3 & 0.0305 & 0.0110 & 0.0115 & 0.0177 \\
\hline
\end{tabular}

Berdasarkan Tabel 7. cluster 3 terpilih sebagai cluster yang memiliki nilai centroid dengan nilai tertinggi (centroid dominan) dengan nilai rata-rata centroid 0.0177, yang mengartikan bahwa letak posisi frame dominan berada pada cluster tersebut. Sehingga cluster tersebut yang akan digunakan sebagai dasar untuk seleksi frame dominan.

Untuk menyeleksi frame dominan, yaitu dengan cara melihat jarak kedekatan anggota cluster 3 terhadap centroid. Anggota cluster yang memiliki jarak terkecil atau terminim terhadap centroid itulah frame dominan. Berikut adalah syntax pada matlab yang digunakan pada saat proses seleksi frame dominan yang dijalankan di command window beserta komentar penjelasannya :

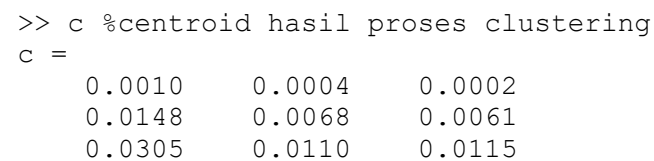

$>$ cmean $=$ mean $(\mathrm{c}, 2)$ omerata-ratakan atribut komponen masing-masing cluster

$>$ cmax=max (cmean) oseleksi centroid dominan (centroid tertinggi)

Hasil dari proses pemeringkatan frame pada syntax di atas dapat ditampilkan pada Tabel 8.

Tabel 8. Peringkat Frame Dominan Dari Tiap Cluster

\begin{tabular}{ccc}
\hline & Cluster 3 & \\
\hline Peringkat & Nilai Jarak Terhadap Centroid & Frame ke- \\
\hline 1 & 0.0008 & 59 \\
\hline 2 & 0.0010 & 36 \\
\hline 3 & 0.0010 & 35 \\
\hline 4 & 0.0010 & 34 \\
\hline 5 & 0.0011 & 38 \\
\hline$\ldots \ldots$ & $\ldots \ldots .$. & $\ldots \ldots$ \\
\hline 37 & 0.0050 & 55 \\
\hline 38 & 0.0052 & 23 \\
\hline 39 & 0.0055 & 61 \\
\hline 40 & 0.0075 & 62 \\
\hline 41 & 0.0076 & 22 \\
\hline & Cluster 2 & \\
\hline Peringkat & Nilai Jarak Terhadap Centroid & Frame- \\
\hline 1 & 0.0004 & 69 \\
\hline 2 & 0.0004 & 71 \\
\hline 3 & 0.0004 & 72 \\
\hline 4 & 0.0005 & 73 \\
\hline 5 & 0.0006 & 65 \\
\hline$\ldots \ldots$ & $\ldots \ldots .$. &
\end{tabular}




\begin{tabular}{ccc}
\hline & Cluster 3 \\
\hline 33 & 0.0062 & 64 \\
\hline 34 & 0.0067 & 21 \\
\hline 35 & 0.0071 & 17 \\
\hline 36 & 0.0079 & 63 \\
\hline \multicolumn{3}{c}{ Cluster 1 } \\
\hline 1 & 0.0005 & Frame ke- \\
\hline 2 & 0.0007 & 13 \\
\hline 3 & 0.0011 & 12 \\
\hline 4 & 0.0011 & 11 \\
\hline 5 & 0.0011 & 2 \\
\hline$\ldots \ldots$ & $\ldots \ldots .$. & 9 \\
\hline 12 & 0.0011 & 10 \\
\hline 13 & 0.0011 & 14 \\
\hline 14 & 0.0021 & 15 \\
\hline 15 & 0.0041 & 16 \\
\hline 16 & 0.0064 &
\end{tabular}

Berdasarkan Tabel 8. hasil peringkat frame dominan dari tiap cluster dapat divisualisasikan menjadi tiga terbaik seperti yang ditunjukkan dalam Gambar 14.

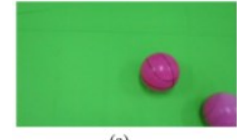

(a)
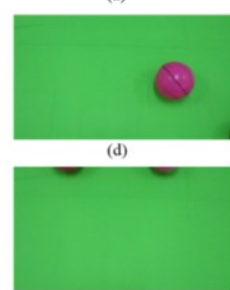

(g)

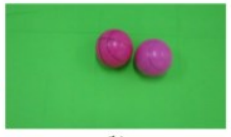

(b)
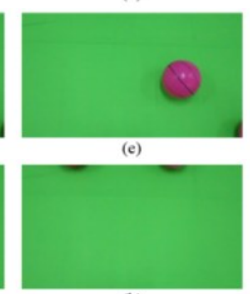

(h)

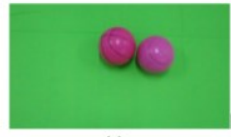

(c)

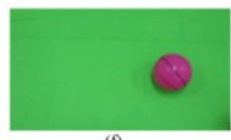

(i)

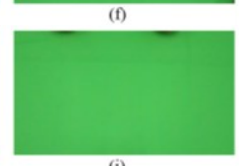

Gambar 14. Visualisasi Tiga Terbaik Frame Dominan Dari Tiap Cluster

Keterangan :

(a) Peringkat 1 frame dominan dari cluster 3 yang dimiliki oleh frame ke59 dengan nilai jarak kedekatan terhadap centroid sebesar 0.000829. (b) Peringkat 2 frame dominan dari cluster 3 yang dimiliki oleh frame ke-36 dengan nilai jarak kedekatan terhadap centroid sebesar 0.000955. (c) Peringkat 3 frame dominan dari cluster 3 yang dimiliki oleh frame ke-35 dengan nilai jarak kedekatan terhadap centroid sebesar 0.000967. (d) Peringkat 1 frame dominan dari cluster 2 yang dimiliki oleh frame ke-70 dengan nilai jarak kedekatan terhadap centroid sebesar 0.000354. (e) Peringkat 2 frame dominan dari cluster 2 yang dimiliki oleh frame ke-69 dengan nilai jarak kedekatan terhadap centroid sebesar 0.000362. (f) Peringkat 3 frame dominan dari cluster 2 yang dimiliki oleh frame ke-71 dengan nilai jarak kedekatan terhadap centroid sebesar 0.000405. (g) Peringkat 1 frame dominan dari cluster 1 yang dimiliki oleh frame ke-13 dengan nilai jarak kedekatan terhadap centroid sebesar 0.000481. (h) Peringkat 2 frame dominan dari cluster 1 yang dimiliki oleh frame ke-12 dengan nilai jarak kedekatan terhadap centroid sebesar 0.000666. (i) Peringkat 3 frame dominan dari cluster 1 yang dimiliki oleh frame ke-11 dengan nilai jarak kedekatan terhadap centroid sebesar 0.001120 .

\section{KESIMPULAN}

Hasil penetapan pola obyek yaitu berupa pola obyek bola RGB dari tiap frame, yang kemudian dilakukan estraksi ciri pola untuk mengambil nilai ciri yang terkandung. Hasil esktrasi ciri digunakan sebagai label frame atau atribut data frame dalam proses clustering. Dengan metode K-Means clustering menghasilkan 3 kali iterasi, dengan 41 data frame teridentifikasi memiliki nilai ciri pola "baik" yang terletak pada cluster 3, 36 data frame teridentifikasi memiliki nilai ciri pola "cukup baik" yang terletak pada cluster 2 dan 16 data frame teridentifikasi memiliki nilai ciri pola "kurang baik" yang terletak pada cluster 1 .

Penyeleksian frame berdasarkan centroid dominan (centroid dengan nilai tertinggi) yang terletak pada cluster 3 yang diperoleh dari proses clustering, dapat diambil tiga terbaik frame dominan dari seluruh rangkaian frame dengan hasil yang diperoleh yaitu frame ke-59, ke-36 dan ke-35

Penelitian ini dapat dikombinasikan dengan pelacakan objek bergerak untuk meminimisasi jumlah frame yang tidak diperlukan dan diterapkan pada real time proses.

\section{UCAPAN TERIMA KASIH}

Peneliti mengucapkan terimakasih kepada Modern Computing Research Center Jurusan Teknologi Informasi Politeknik Negeri Samarinda dan Hibah Unit Penelitian \& Pengabdian Masyarakat Politeknik Negeri Samarinda dengan nomor kontrak 1211/PL7/LK/2019 - DIPA Direktorat Riset dan Pengabdian Masyarakat, Direktorat Jendral Penguatan Riset dan Pengembangan Kementerian Riset, Teknologi dan Pendidikan Tinggi.

\section{DAFTAR PUSTAKA}

AGGARWAL, C. C. \& REDDY, C. K. 2013. Data Clustering : Algorithms and Applications, Boca Raton, Florida, CRC Press.

FIRDAUSY, K., SUTIKNO, T. \& PRASETYO, E. 2007. Image Enhancement Using Contrast Stretching On RGB and IHS Digital Image. TELKOMNIKA Indonesian Journal of Electrical Engineering, 5, 45-50.

KADIR, A. \& SANTOSO, A. 2013. Teori dan Aplikasi Pengolahan Citra, Yogyakarta, Andi Publisher.

KOTSARENKO, Y. \& RAMOS, F. 2010. Measuring Perceived Color Difference Using YIQ NTSC Transmission Color Space In Mobile Applications. Programación Matemática y Software, 2, 27-43.

MUNIR, R. 2004. Pengolahan Citra Digital Dengan Pendekatan Algoritmik, Bandung, Informatika.

PUTRA, A. B. W., GAFFAR, A. F. O., WAJIANSYAH, A. \& QASIM, I. H. Feature-Based Video Frame Compression Using Adaptive Fuzzy Inference System. 2018 International Symposium on Advanced Intelligent Informatics (SAIN), 29-30 Aug. 2018 2018. 49-55.

PUTRA, A. B. W., RIHARTANTO \& ALHUMAERAH, A. M. 2019. Penerapan K-Means Clustering Dalam Pengelompokan Lipstik Matte Lip Cream Berdasarkan Warna RGB. Jurnal Sains Terapan (JST), 5, 28-35. 
PUTRI, E. 2018. Pengujian Citra Jeruk Baby Untuk Mengetahui Area Cacat Menggunakan Klasifikasi Pixel. Jurnal Nasional Pendidikan Teknik Informatika (JANAPATI), 7, 73-79.

PUTRI, M. H. H., PUTRA, A. B. W. \& GAFFAR, A. F. O. 2018. Ekstraksi Ciri Citra Wajah Manusia Menggunakan Metode Mean Absolute Error (MAE) Dan Discrete Cosine Transofrm (DCT) Pada Klasifikasi Usia Manusia. Seminar Nasional Teknologi, Inovasi dan Aplikasi di Lingkungan Tropis. Samarinda: Fakultas Teknik Universitas Mulawarman.

SARI, R. J., GAFFAR, A. F. O. \& PUTRA, A. B. W. 2018. Identifikasi Obyek Bergerak Berbasis Segmentasi Warna RGB. Prosiding Seminar Ilmu Komputer dan Teknologi Informasi, Vol. 3.

SHUPING, Y. \& XINGGANG, L. 2005. Key Frame Extraction Using Unsupervised Clustering Based on a Statistical Model. Tsinghua Science And Technology, Volume 10, pp169-173.

SYAFI'I, S. I., WAHYUNINGRUM, R. T. \& MUNTASA, A. 2015. Segmentasi Obyek Pada Citra Digital Menggunakan Metode Otsu Thresholding. Jurnal Informatika, 13, 1-8.

ZHOU, H., WU, J. \& ZHANG, J. 2014a. Digital Image Processing: Part I.

ZHOU, H., WU, J. \& ZHANG, J. 2014b. Digital Image Processing: Part II 
Halaman ini sengaja dikosongkan 